〔43〕種々の方法により製造されたポリビニル アルコールの分子内環生成反応

(1963 年 10 月 3日受理)

桜田一郎*・坂口康義**・椎木善弥*

\begin{abstract}
要＼cjkstart旨アイソタクチックポリビニルエーテルから誘導されたアイソタクチックポリビニルアルコール (isot-PVA) およびポリトリフルオロ酢酸ビニルから誘導されたシンジオタクチックポリビニルアルコール (synd-PVA) をアセトアルデヒドによりアセタール化した。isot-PVA は synd-PVA よりも大きい反応性 さ示した。synd-PVA および各種の条件下でラジカル重合により製造したポり酢酸ビニルから誘導された PVA は,アセタール化に対して互にほぼ同じ応性を示した。isot-PVA のホウ酸およびホウ砂との反応性 も他の PVA 試料のそれらよりも大きい。これらの結果およびポり酿酸ビニルのケン化反応に関する結果か ら,ラジカル重合ポリビニルエステルから䚽導された PVA 試料は似た立体構造を持つと考えられる。これ らの PVA 試料の結晶性の差異の原因を検即し，主原因の一つとしてポリマー中の短い分枝を提案した。
\end{abstract}

\section{1. 緒言}

著者らは既報において, 立体構造の異なるポリ酶酸ビ ニル $(\mathrm{PVAc})$ のケン化速度が明りょうに相違することを 認め,この結果について考察を行なった 条件下におけるラジカル重合により製造された PVAc 試料のケン化速度は互にほほ同じであることを認め,こ れらの試料の立体構造は大差ないものと推定した ${ }^{1)}$ 。

立体構造に依存することが期待される PVA 系ポリ マーの反応としては, 前述以外に PVA のアセタール化 が考えられる。<smiles>[R]C(=O)CC(O)CC(O)CC</smiles>

$\mathrm{R}$

低分子多価アルコールのアセタール化に関しては, 従 来かなりの研究が行なわれている。Boukr らは, シス 位置にある $\mathrm{OH}$ 基間の 6 員環アセタールが最も形成さ れやすく, ついで立体配位の固定していない $\mathrm{OH}$ 基間 の 6 員環が形成されやすく,トランス位置にある $\mathrm{OH}$ 基 間の 6 員環, および 5 員環ならびに 7 員環は形成されに くく, また生成アセタールの安定性も前述と同し傾向に あるといら一般的な法則を提出している2)。これらの結 果から, PVA のア七タール化に対する反応性は試料の 立体構造に依存することが期待されるので, 数種のPVA 試料についてこの反応性を比較検討した。また比較のた め, 数種の低分子多価アルコールのアセタール化につい

* 京都大学工学部高分子化学教室 (京都市左京区吉田)

** 甲南大学理学部応用化学教室 (神戸市東䧽区本山町)
ても若干の実験を行なった。

従来糖類などが水溶液中に掞いてホウ酸およびホウ砂 と反応し, これに伴って溶液の $\mathrm{pH}$ が低下し, 電導度が 増大することが知られている8)。この反応の本性はまだ 十分には明らかでないが, この反応により環状構造が形 成されると考えられており，反応性は糖類などの分子中 の $\mathrm{OH}$ 基の立体配置に依存することが指摘されている。 PVA もホウ酸・ホウ砂と同様な反応を行ならことが 定性的に認められているか。ししだって，PVA とホウ 酸・ホウ砂との反応性も試料の立体構造に依存すること が期待されるので, この点について検討した。なお比較 のため, 数種の低分子多価アルコールについても若干の 実験を行なった。

反応性の観点からは，各種の方法により製造されたラ ジカル重合ポリビニルェステルの立体構造は大差がない と推定されたので,これらから誘導された PVA 試料の 結晶性の差異の原因についても若干の検討を行なった。

\section{2. アセタール化}

2.1 試 料

PVA 試料としては既報”と同一のものを用いた。す なわち, 試料 A はアイソタクチックポリビニルエーテ ルから誘導されたアイソタクチック PVA (isot-PVA) であり, 試料 $\mathrm{B}$ はポリトリフルオロ酢酸ビニルから誘 導されたシンジオタクチシティが高いと考えられる PVA (synd-PVA) であり, 試料 C.D.E・F・I は異なる 条件でのラジカル重合により製造したポリ酶酸ビニルか ら誘導された PVA である。

低分子アルコールとしては次式のものを用いた。

2.2 低分子多価アルコールのアセタール化

まず前述の低分子多価アルコールならびに普通の PVA 試料 (C) を水溶液中でホルマール化して, 多価厂 ルコール分子中の $\mathrm{OH}$ 基間の 空間的距離の影響を検討 


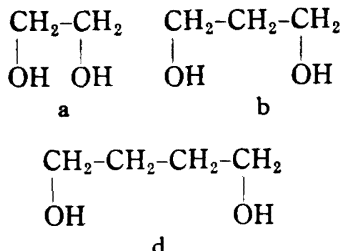<smiles>CC(O)C(C)O</smiles><smiles>OCC(O)C(O)C(O)C(O)CO</smiles><smiles>OCC(O)C(O)C(O)C(O)CO</smiles>

した。この際，亜硫酸ソーダ法による反応液中の残存遊 離アルデヒドの定量からアセタール化度を求めた。本実 験の条件では，へミアセタールあるいは分子間アセター ルはほとんど形成されず，消費されたアルデヒドのほと んどは分子内アセタール環の形で存在すると考えられ る。これに関する実験の条件と結果は Table 1 に示す とおりである。

Table 1 からわかるように, アセタール化度は 6 員環 だけが形成される b および PVA-C が最も高く， 6 員 環も形成される $\mathrm{g} \cdot \mathrm{f} \cdot \mathrm{e}$ がこれに次ぎ, 6 員環が形成され ないc・a・d は最も低い。しかし，PVA-C とbを比・ ると前者の方がアセタール化度が高く， 5 員環だけが形

Table 1. Acetalization of various polyhydric alcohols with formaldehyde in water.

$[\mathrm{OH}] 1 / 3 \mathrm{M}$, [HCHO] $1 \mathrm{M},\left[\mathrm{H}_{2} \mathrm{SO}\right.$, $] 2 / 3 \mathrm{M}\left({ }^{*} 1 / 3 \mathrm{M}\right)$, $65^{\circ} \mathrm{C}$

\begin{tabular}{|c|c|c|c|c|c|}
\hline \multirow{2}{*}{ Alcohol ${ }^{*}$} & \multicolumn{5}{|c|}{$\begin{array}{c}\text { Conversion }(\underset{\mathrm{mol}}{\mathrm{m}} \mathrm{)}) \text { after following } \\
\text { time }(\mathrm{hr})\end{array}$} \\
\hline & 6 & 15 & 27 & 50 & $23^{*}$ \\
\hline a & 3 & 4 & - & 4 & 3 \\
\hline b & 24 & 25 & 26 & 31 & - \\
\hline c & 11 & 12 & - & 15 & - \\
\hline$d$ & - & 3 & 3 & - & - \\
\hline $\mathrm{e}$ & - & 14 & 14 & - & - \\
\hline f & - & 15 & - & 19 & 16 \\
\hline $\mathrm{g}$ & - & 17 & - & 21 & 19 \\
\hline PVA-C & $29 * *$ & $30 * *$ & - & - & $28^{* *}$ \\
\hline
\end{tabular}

* Formulae of the corresponding alcohols are given in the text.

** Acetalization products precipitated.
成される c と a を比へると前者の方がアセタール化度 が高く，立体異性体である $\mathrm{f}$ と $\mathrm{g}$ とのアセタール化度 はわずかではあるが明りょらに異なる。これらの事実か らもアセタール環の形成が $\mathrm{OH}$ 基間の空間距離により

影響されていることは明らかである。

\section{3 各種のポリピニルアルコール試料のアセタール 化}

次に立体構造の異なる PVA 試料 A·B・C を水ージオ キサン混合液中でアセトアルデヒドにより，アセタール 化した。3 時間反応後に試料 A の溶液がかすかに濁り 始めたので，ここで触媒酸を中和し，水に注入してポリ マーを沈殿させ，精製，乾燥した。試料のアセタール化 度は硫酸分解, 生成アルデヒドの水蒸気蒸留, $\mathrm{NaHSO}_{8}$ と アルデヒドとのコンプレックス形成の常法により定量し た。これに関する実験結果は Table 2 に示した。

Table 2. Acetalization of isotactic, syndiotactic and atactic polyvinyl alcohol with acetaldehyde in a water-dioxane mixture ( $3: 5$ by volume).

[PVA] 0.0258 base $\mathrm{M},\left[\mathrm{H}_{2} \mathrm{SO}\right.$ ] $0.10 \mathrm{~N}, 50^{\circ} \mathrm{C}, 3 \mathrm{hr}$

\begin{tabular}{l|c|c|c}
\hline \multicolumn{1}{|c|}{ PVA } & $\begin{array}{c}\mathrm{CH}_{3} \mathrm{CHO} \\
\text { equivalent/ } \\
\text { PVA }\end{array}$ & $\begin{array}{c}\text { Degree of } \\
\text { acetalization } \\
\text { (mol\%) }\end{array}$ & $\begin{array}{c}\text { Equilibrium } \\
\text { constant }\end{array}$ \\
\hline A (isot) & 0.974 & 68.4 & 3100 \\
B (synd) & $n$ & 61.5 & 1440 \\
C (atac) & $"$ & 61.5 & 1440 \\
\hline A (isot) & 1.83 & 68.7 & - \\
B (synd) & $"$ & 65.1 & - \\
C (atac) & $"$ & 65.6 & - \\
\hline
\end{tabular}

Table 2 から明らかなように, A のア七タール化度 は他の試料よりも高く，B と C のア七タール化度はほ とんど同じである。この反応性の差異は既報のポリ 酢酸ビニルのケン化の反応性の差異に対応している。 $\mathrm{CH}_{3} \mathrm{CHO}$ の使用量が 0.974 equivalent/PVA の場合,反 応は平衡に達していると仮定して，反応の平衡定数を算 出した。この際, 坬立水酸基の存在に対する補正" なった。平衡定数の值は Table 3 に示すとおりであり， $\mathrm{A}$ は $\mathrm{B}$ および C より約 2 倍大きい值を示す。

次に異なる条件でラジカル重合して得られたポリ酶酸 ビニルから誘遒された PVA 試料のアセタール化挙動 を若干の反応条件で比較した。この結果は Table 3 に 示すとおりであり，試料 D.E.F.I のア七タール化度は ほぼ同一である。この結果はこれらの試料の出発ポリ酢 酸ビニルのケン化速度がほぼ同じであるという既報の結 果に対応している。 
Table 3. Acetalization of polyvinyl alcohols derived from polyvinyl acetates obtained by radical polymerization under various conditions.

\begin{tabular}{|c|c|c|c|c|c|c|c|c|}
\hline Sample & $\begin{array}{l}{[\mathrm{PVA}]} \\
(b \mathrm{~mol} / l)\end{array}$ & \multicolumn{2}{|c|}{$\begin{array}{c}\text { Aldehyde } \\
\text { equivalent/PVA }\end{array}$} & $\begin{array}{l}{\left[\mathrm{H}_{2} \mathrm{SO}_{4}\right]} \\
\quad(N)\end{array}$ & $\begin{array}{l}\text { Volume ratio of water } \\
\text { to dioxane in solvent }\end{array}$ & $\begin{array}{l}\text { Temp. } \\
\left({ }^{\circ} \mathrm{C}\right)\end{array}$ & $\underset{(\mathrm{hr})}{\operatorname{Time}}$ & $\begin{array}{l}\text { Degree of acetali- } \\
\text { zation }(\mathrm{mol} \%)\end{array}$ \\
\hline D & 0.075 & $\mathrm{HCHO}$ & 0.22 & 2.00 & $10: 0$ & 40 & 70 & 21.5 \\
\hline $\mathrm{E}$ & $"$ & $"$ & & $"$ & $"$ & $"$ & $"$ & 20.2 \\
\hline $\mathrm{F}$ & $"$ & $"$ & & $"$ & $"$ & $"$ & $"$ & 20.8 \\
\hline $\mathrm{D}$ & 0.0424 & $\mathrm{CH}_{3} \mathrm{CHO}$ & 0.71 & 0.05 & $6: 4$ & 50 & 47 & 15.7 \\
\hline $\mathrm{E}$ & $n$ & 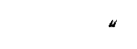 & & $n$ & $"$ & $"$ & $"$ & 15.9 \\
\hline $\mathrm{F}$ & " & " & & $"$ & " & $"$ & " & 14.2 \\
\hline $\mathrm{D}$ & 0.0267 & $\mathrm{CH}_{3} \mathrm{CHO}$ & 4.69 & 0.15 & $6: 4$ & 50 & 44 & 65.1 \\
\hline $\mathrm{E}$ & $"$ & $"$ & & $"$ & $"$ & $"$ & $"$ & 66.1 \\
\hline $\mathrm{F}$ & $"$ & $"$ & & $"$ & $"$ & $"$ & $"$ & 64.7 \\
\hline D & 0.0216 & $\mathrm{CH}_{3} \mathrm{CHO}$ & 1.59 & 0.03 & $3: 5$ & 50 & 44 & 51.6 \\
\hline I & " & $"$ & & $"$ & $"$ & $"$ & $"$ & 51.2 \\
\hline
\end{tabular}

なお松本らも PVA を本研究と若干異なる条件でアセ タール化を行ない, 平衡定数は isot-PVA の方が syndPVA よりも大きいという結果を得ている ${ }^{6)}$ 。

\section{3. ホウ酸およびホウ砂との反応}

ホウ酸およびホウ砂の水溶液の $\mathrm{pH}$ が榶類などとの反 応により変化することが認められているので3), 各種の 多価アルコール試料とホウ酸・ホウ砂上の反応性を $\mathrm{pH}$ 測定により定性的に比較検討した。

\section{1 低分子多価アルコールの反応}

まずホウ酸またはホウ砂の本溶液に各種の低分子多佂 アルコールを添加して $\mathrm{pH}$ 変化を調べた。 $\mathrm{pH}$ は日立一

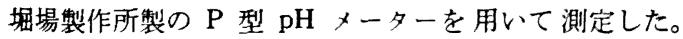
これに関する結果は一括して Table 4 に示した。この 表からわかるように, 水溶液の $\mathrm{pH}$ は分子中で $\mathrm{OH}$ 基 の立体配置が固定されている $\mathrm{f}$ および $\mathrm{g}$ の添加により 明りょうに低下するが，その他のアルコールを添加して もほとんど変化しない。

\section{2 各種の PVA 試料の反応}

次に各種の PVA 試料がホウ酸・ホウ砂水溶液の $\mathrm{pH}$ に及ぼす影響を検討した。この結果は Table 5 に示す とおりである。この表からわかるよらに，水溶液の $\mathrm{pH}$ は isot-PVA (A) の添加によりやや明りょうに低下して いるが，その他の PVA 試料を添加しても明りょうには 変化しない。このことから, isot-PVA は他の PVA 試 料よりもホウ酸・ホウ砂と環状反応生成物を形成しやす く, 他の PVA 試料の反応性はいずれも小さくて, 互に 大差がないと結論できる。この結果は前述のアセタール 化の場合と同じ傾向である。

$$
\begin{gathered}
\text { 4. ポリヒヒニルアルコールおよびヒニルアル } \\
\text { コール・アリルアルコール共重合物のアセ } \\
\text { タール化物の溶液中における広がり }
\end{gathered}
$$

\section{1 ポリヒニルアルコール試料の立体構造以外の 構 造的差異 \\ 前述および既報"}

Table 4. The effects of various polyhydric alcohols on $\mathrm{pH}$-values of aqueous solutions of boric acid or borax.

I. $\left[\mathrm{H}_{3} \mathrm{BO}_{3}\right] 0.10 \mathrm{M},[\mathrm{OH}] 0.25 \mathrm{M}, 20^{\circ} \mathrm{C}$

\begin{tabular}{c|cc|c|c|c|c|c|c|c}
\hline \hline Alcohol & None & $\mathrm{a}$ & $\mathrm{b}$ & $\mathrm{c}$ & $\mathrm{d}$ & $\mathrm{f}$ & $\mathrm{g}$ \\
\hline $\mathrm{pH}$ & 5.40 & 5.40 & 5.39 & 5.35 & 5.32 & 4.27 & 4.15 \\
\hline
\end{tabular}

II. $\left[\mathrm{Na}_{2} \mathrm{~B}, \mathrm{O}_{7}\right] 0.025 \mathrm{M},[\mathrm{OH}] 0.25 \mathrm{M}, 20^{\circ} \mathrm{C}$

\begin{tabular}{c|cc|c|c|c|c}
\hline Alcohol & None & b & c & f & g \\
\hline $\mathrm{pH}$ & 8.99 & 8.92 & 8.87 & 8.15 & 8.06 \\
\hline
\end{tabular}


Table 5. The effects of various PVA's on $\mathrm{pH}$-values of aqueous solutions of boric acid or borax.

I. $\left[\mathrm{H}_{3} \mathrm{BO}_{3}\right] 0.10 \mathrm{M},[\mathrm{PVA}] 0.25$ base $\mathrm{M}, 20^{\circ} \mathrm{C}$

\begin{tabular}{c|c|c|c|c|c|c}
\hline \hline PVA & None & A & B & C & E & F \\
\hline $\mathrm{pH}$ & 5.35 & 4.98 & 5.38 & 5.29 & 5.37 & 5.41 \\
\hline
\end{tabular}

II. $\left[\mathrm{Na}_{2} \mathrm{~B}_{4} \mathrm{O}_{7}\right] 0.025 \mathrm{M}$, [PVA] 0.25 base $\mathrm{M}, 20^{\circ} \mathrm{C}$

\begin{tabular}{c|c|c|c|c|c|c}
\hline \hline PVA & None & A & B & C & E & F \\
\hline $\mathrm{pH}$ & 9.16 & 8.85 & 9.11 & 9.13 & 9.09 & 9.04 \\
\hline
\end{tabular}

ル重合によって製造された結晶性の明りょらに異なる PVA 試料およびこれらに対応するPVAc 試料の化学 反応性はほぼ同じであり,この点からはこれらの試料の 立体構造は大差がないと考えられる。これらのPVA 試 料の結晶性の差異が立体構造のわずかの差に起因してい るという考えはまったく否定することはできないが，結 晶性の差異の主原因は立体構造以外の構造的差異である と考える方がより妥当のように思われる。

従来の研究結果を通覧すると, このような構造的差異 としては 1,2-グリコール結合量, カルボニル基含有量 の差異は考えにくい。可能性が多いと考えられる構造的 差異は分岐である。従来の結果から，PVA 分子中には ポリマー連鎖移動に基く長い分岐はほとんど存在しない と考えられるが，短い分岐が存在しており，これが結晶 性に大きい影響を与えている可能性は十分考えられる。 たとえば，次式に示すように主鎖の水素原子の分子内連 鎖移動が起こると，ポリエチレンにお汀ると同様に短い 分岐が生成する。<smiles>CO[C@H](C)[C@H](C)OC(C)=O</smiles>

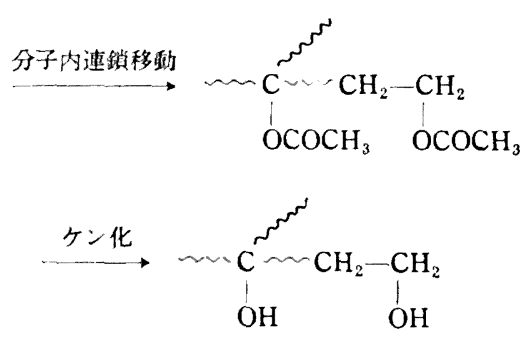

このように考えると，PVA 分子中には分岐あたり 1 個の一称水酸基が存在することになる。長井らは $9.1 \mu$ の赤外線吸収バンドのひずみから，普通の PVA 中にか
なりの量の第一級水酸基が存在する可能性を指摘してい る7)。しかし, 第一級水酸基と第二級水酸基の特性吸收 の波長がごく近いので, 赤外線スペクトルから比較的少 量の第一級水酸基の存在を確認することはむずかしいよ らに思われる。

PVA の分子構造に関連して松本らの興味ある報告が あるふ。松本らは PVAのアセトアセタール化物の溶液 中における広がりが，同一分子量の試料について低温重 合物の方が高温重合物よりも明りょらに大きい事実を見 出している。彼らはその原因を試料 PVA の立体構造の 差巽に帰しているが，著者らの反応性に関する実験結果 などから，この考えは受计入れにくい。この事実は短い 分岐の存在を考えると，次に述べるように理解すること ができる。

前述した 2 価アルコール (a) が (c) よりもアセタール 化されにくく、また (b) が 1,3-ブタンジオールよりア セタール化されにくいことから，分岐末端に存在する第 一級水酸基は同一分子中の隧接水酸基とアセタール環を 形成しにくく, 他の分子中の水酸基との閒で分子間ア七 タールを形成する可能性が大きいと考えられる。このよ らな分子間アセタール化により生じた分子は長い分岐を 持つことになり，溶液中における広がりは同一分子量を 持つ直嗩状ポリマーよりも小さくなる。高温重合物は低 温重合物に比へて第一級水酸基の含有量が多いために, アセタール化物の長い分岐の密度が高くなり, 溶液中に おける広がりが小さくなる。な的第一級水酸基と同一分 子中の他の水酸基間に大きいアセタール環が形成される と考えても，アセタール化物の広がりに関しては同し結 論が導かれる。

このような分子間アセタール化の考えを確かめる目的 で，第一級水酸基を含む短い分岐を持つ PVA のモデ ル物質として，少量のアリルアルコール基本分子を含む PVA 共重合物を製造し，これと純 PVA のアセタール 化物の溶液中に㧍ける広がりを粘度測定により比較検討 した。 
Table 6. Acetalization of polyvinyl alcohol and vinylalcohol-allyl alcohol copolymer ( $98: 2$ by $\mathrm{mol}$ ) fractions with acetaldehyde.

Water-dioxane mixture $\left(3: 5\right.$ by vol), $0.03 \mathrm{~N} \mathrm{H}_{2} \mathrm{SO}_{4}, 50^{\circ} \mathrm{C}$

\begin{tabular}{c|c|c|c|c}
\hline \hline No. & Conc. of polymer & $\begin{array}{c}\mathrm{CH}_{3} \mathrm{CHO} \\
(\mathrm{g} / \mathrm{l})\end{array}$ & $\begin{array}{c}\text { Reaction time } \\
(\mathrm{hr})\end{array}$ & $\begin{array}{c}\text { Degree of Acetalization } \\
(\mathrm{mol} \%)\end{array}$ \\
\hline 1 & 1.25 & 3.4 & 20 & 46 \\
2 & 0.28 & 12.3 & 44 & 55 \\
3 & 0.88 & 4.9 & 51 & 64 \\
4 & 0.26 & 16.4 & 53 & 66 \\
\hline
\end{tabular}

\section{2 出発ポリマー}

酢酸ビニル単独, あるいは酢酸ビニル98モル $\%$ 酢酸アリル 2 モル\%の混合物を $0.1 \%$ AIBN を開始 剤に用いて $40^{\circ} \mathrm{C}$ で塊状重合を行なった。生成ポリマー は常法により分離, 精製後, 完全にヶン化した。ケン化 物を水を溶媒, $n$-プロパノールを沈殿剤に用いて分別沈 殿法により分別した。

\section{3 アセタール化}

前述の両種の分別試料を Table 6 に示す条件でアセ タール化し, 常法により生成ポリマーを分離, 精製, 分 析した。同一アセタール化条件で得られたポリマーのア セタール化度は, 出発試料にほぼ無関倸に一定であった。

\section{4 出発ポリマーおよびアセタール化物の溶夜粘度}

前述した出発ポリマーおよびア七タール化物の濃度 $0.25 \mathrm{~g} / 100 \mathrm{cc}$ の溶液の粘度索 $30^{\circ} \mathrm{C}$ で測定した。溶媒 は出発ポリマーに対しては水，アセタール化物に対して は水ージオキサン混合液である。出発ポリマーの $\eta_{s p} / c$ とアセタール化物のそれとの関倸は一括して Fig. 1 に 示した。

Fig. 1 からわかるように，いずれの場合においても， 出発ポリマーの $\eta_{s p} / c$ が同しときは, アセタール化物の 粘度は共重合物の方が純 PVA よりも明りょうに高い。 出発ポリマーにおいては, $\eta_{s} / c$ の值が同一の場合には, 共重合物の方が純 PVA よりも重合度はむしろやや低、 と推定されるから，アセタール化物の粘度が共重合物の 方が高、事実は，共重合物の方が分子間アセタール化が より起こっていることを示しているものと解嶓すること ができる。したがって PVA 中には第一級水酸基が存在 し，この量が重合条件により変化すると考えることによ り，松本らの事実を理解することができる。また第一級 水酸基を含む短い分岐が PVA 試料の結晶性の差異の主 原因である公算が大きい。なお，PVA のアセタール化 物の溶液粘度はわずかの分子間アセタールの形成によっ て大きく変化しらるから，この場合に分子間アセタール 化が起こっているという考えは, 低分子多価アルコール の分子間アセタール化はほとんど起こらないという，既 述の考えと矛盾するものではない。

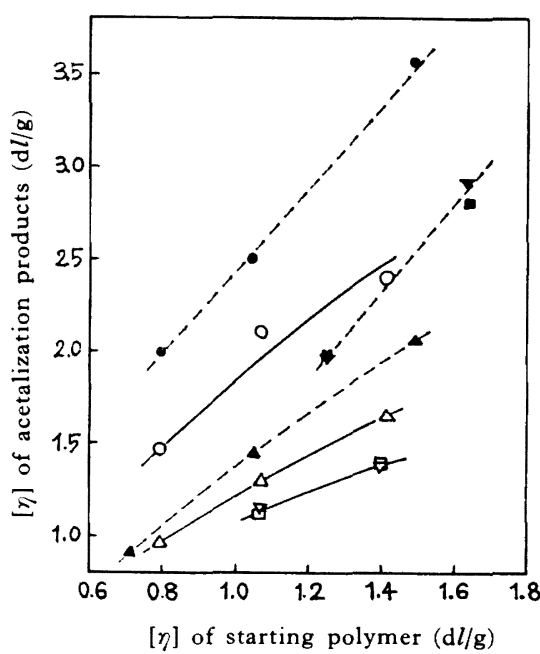

$\begin{array}{lllll}\text { No. of acetalization } & 1 & 2 & 3 & 4 \\ \text { Polyvinyl alcohol } & \bigcirc & \triangle & \square & \nabla \\ \text { Copolymer } & \bullet & \Delta & \square & \nabla\end{array}$

Fig. 1. Relationships between [ $\eta$ ] of polyvinyl alcohol and vinyl alcohollaly alcohol copolymer ( $98: 2$ by $\mathrm{mol}$ ) fractions in water at $30^{\circ} \mathrm{C}$ and $[\gamma]$ of their acetalization products in a waterdioxane mixture $\left(3: 5\right.$ by volume) at $30^{\circ} \mathrm{C}$.

\section{5. 結言}

本報および既報 ${ }^{1)}$ を通じて，PVA および PVAc のあ る特定の化学反応の反応性が, 試料ポリマーの立体構造 に明りょうに依存することを示した。また化学反応性の 観点から, ラジカル重合により製造されたポリビニルェ ステルおよび PVA 試料の立体構造は実験の筙囲では大 差がないと結論し,これらの PVA 試料の結晶性の差異 の主原因として短い分岐を推論した。PVA 系高分子の 立体構造と化学反応性の関係, ラジカル重合による立体 構造の明りょうに異なる PVA 系高分子の製造などに関 しては, 現在さらに研究を続けている。

付 記：本研究の一部は昭和 38 年度文部省科学研究費 (総合 
研究)により行なった。哚く感颜する。本報告の概要は高分子 学会第 11 回, 第 12 回年次大会 (1962 年 5 月, 名古屋, 1963 年 5 月, 東京) に扔いて発表した。

\section{文献}

1）桜田一郎, 坂口康義, 椎木善弥, 西野 潤: 高化, 21, 241 (1964)

2) S. A. Boukr et al.: J. Chem. Soc., 905(1952)

3) J. Böeseken : Advances in Carbohydrate Chemistry, 4, 35, 171, 189, 261 (1949)； その他

4) H. Deuel, H. Neukon: Makromol. Chem., 3, 13 (1949); 辻和一郎, 今井政三：日本化学繊維研究所
講演集, 9, 1(1952); 本山卓彦, 岡村誠三：高化, 11, 23(1954); 岡田 晃, 桜田一郎: 高化, 15, 491, 496(1958); 廉 成根: 日本化学繊維研究所講演集, 15, 1 (1958)

5）坂口康義：高分子展望，10，39(1953)

6) 藤井 洌, 浮田純二, 松本昌一：高分子研究発表会 (1962 年 11 月, 大阪); 松本昌一, 安井昭夫, 藤井 洌, 藤原鎮男, 藤原 䛊: 高分子学会第 12 回年次 大会 (1963 年 5 月, 東京)

7) 長井栄一，相根典男：工化，59，794(1956)

8）松本昌一, 大柳康治：J. Polymer Sci., 37, 558 (1959)

\title{
Intramolecular Reactions of Polyvinyl Alcohols Prepared by Various Procedures
}

\author{
By Ichiro Sakurada*, Yasuyoshi Sakaguchi** and Zenya Shiiki*
}

Isotactic polyvinyl alcohol (isot-PVA) derived from isotactic polyvinyl ether and syndiotactic polyvinyl alcohol (synd-PVA) derived from polyvinyl trifluoroacetate were acetalized with acetaldehyde. Isot-PVA showed a larger reactivity than synd-PVA, however synd-PVA and PVA's derived from polyvinyl acetate prepared by radical polymerization under various conditions showed nearly the same reactivity to each other. The reactivities of isot-PVA with boric acid and borax were also larger than those of the other PVA's. From these results and the previously reported one for the saponification of polyvinyl acetate samples, PVA's derived from polyvinyl esters prepared by radical polymerization seem to have similar steric structures. Short branches in the polymer molecule may be the chief reason for the difference of the crystallinity of these PVA samples.

* Department of Polymer Chemistry, Kyoto University (Kyoto)

** Department of Applied Chemistry, Kōnan University (Higashinada-ku, Kōbe) 